\title{
Inleiding op het themanummer
}

\author{
W. Meeus • S. Branje $\cdot$ W. Vollebergh
}

In 1990 publiceerde het Nederlands Tijdschrift voor de Psychologie een themanummer over de adolescentie. Naast enkele empirische studies bevatte het themanummer een tweetal overzichtsartikelen: Koops (1990) beschreef het adolescentie onderzoek in Nederland en Europa en Marcoen (1990) beschouwde het onderzoek in Vlaanderen. Beide auteurs waren niet lovend over de stand van zaken. Ze vonden het onderzoek te versnipperd, te veel op hedendaagse maatschappelijke problemen gericht en te weinig ontwikkelingspsychologisch. Koops (1990, p. 245) zag ook weinig toekomstmogelijkheden. Het adolescentieonderzoek zou zich niet kunnen voegen in 'de streng empirisch-analytische benadering van de ontwikkelingspsychologie'. Ook constateerde hij (Koops, 1990, p. 245): 'De ontwikkelingspsycholoog die onderzoek naar ontwikkelingsverschijnselen in de adolescentie verricht, doet dat gewoonlijk incidenteel (..).'

Dit themanummer laat zien dat beide auteurs te pessimistisch waren over (de toekomst van) het adolescentieonderzoek. Internationaal bestaan er twee bloeiende associaties op het gebied van adolescentie: in Europa is dat de European Association for Research on Adolescence (EARA) en in de Verenigde Staten de Society for Research on Adolecence (SRA). Beide verenigingen floreren, houden goed bezochte tweejaarlijkse congressen en hebben een eigen tijdschrift, respectievelijk Journal of Adolescence en Journal for Research on Adolescence. Ook in Nederland is de situatie inmiddels veel beter. Er zijn drie onderzoeksgroepen die zich voornamelijk op de adolescentie richten: die van Engels in Nijmegen, die van Meeus in Utrecht en die van Vollebergh in Leiden. Daarnaast is er bij de ontwikkelingspsychologische groepen van Van Aken in Utrecht, Koot aan de vU Amsterdam, Van Geert in Groningen en Westenberg in Leiden substantieel aandacht voor ontwikkeling in de adolescentie.
Voor het merendeel van deze groepen geldt dat ze gespecialiseerd zijn in longitudinaal onderzoek, het instrument bij uitstek om ontwikkelingsprocessen te beschrijven en verklaren.

Koops en Marcoen stelden destijds ook vast dat adolescentieonderzoekers een sterke oriëntatie op maatschappelijke problemen vertonen. Die oriëntatie is gebleven en maakte ook dat adolescentieonderzoekers probleemloos aansluiting konden vinden bij de ontwikkelingspsychopathologie die vanaf de jaren negentig opkwam.

Dit themanummer geeft een indruk hoe het Nederlandse onderzoek naar ontwikkelingspsychopathologie in de adolescentie er momenteel uitziet. Een korte typering: drie van de vijf artikelen (Delsing e.a., Branje e.a. en Stevens e.a.) analyseren zowel internaliserend als externaliserend probleemgedrag, terwijl Wijsbroek e.a. en Akse e.a. zicht richten op internaliserend probleemgedrag. Twee studies (Delsing e.a. en Akse e.a.) presenteren longitudinale data, twee studies besteden expliciet aandacht aan allochtone adolescenten (Stevens e.a. en Wijsbroek e.a.) en alle studies gebruiken geavanceerde statistische methoden: structurele vergelijking, loglineaire analyse en latente klasseanalyse. Inhoudelijk laten de studies onder andere zien dat persoonlijkheid niet stabiel is in de adolescentie (Akse e.a.), dat een ambivalente acculturatie in het hedendaagse Nederland vooral bij allochtone meisjes tot probleemgedrag leidt (Stevens e.a.), dat allochtone adolescenten angstiger zijn dan autochtone (Wijsbroek e.a.), dat dat probleemgedrag over tijd meer invloed heeft op het gezinsfunctioneren dan andersom (Delsing e.a.), en dat een negatieve manier van probleemoplossen vooral aanleiding geeft tot internaliserend probleemgedrag (Branje e.a.). 
De voorspelling van Koops uit 1990 is niet uitgekomen. Dit themanummer laat zien dat het hedendaagse Nederlandse adolescentieonderzoek bloeit als nooit tevoren. Wij voorspellen dat dit de komende vijftien jaar zo zal blijven. We nodigen onze toekomstige collega's uit om in 2020 in dit tijdschrift na te gaan of wij het bij het rechte eind hadden of niet.

\section{Literatuur}

Koops, W. (1990). Adolescentie als thema in de ontwikkelingspsychologie. Nederlands Tijdschrift voor de Psychologie, 45, 241249.

Marcoen, A. (1990). Facetten van het adolescentiepsychologisch onderzoek in Vlaanderen. Nederlands Tijdschrift voor de Psychologie, 45, 250-258. 